\title{
Glaucoom: druk, druk, druk...
}

Citation for published version (APA):

Webers, C. A. B. (2011). Glaucoom: druk, druk, druk... Maastricht University. https://doi.org/10.26481/spe.20110909cw

Document status and date:

Published: 09/09/2011

DOI:

$10.26481 / \mathrm{spe} .20110909 \mathrm{cw}$

Document Version:

Publisher's PDF, also known as Version of record

\section{Please check the document version of this publication:}

- A submitted manuscript is the version of the article upon submission and before peer-review. There can be important differences between the submitted version and the official published version of record.

People interested in the research are advised to contact the author for the final version of the publication, or visit the DOI to the publisher's website.

- The final author version and the galley proof are versions of the publication after peer review.

- The final published version features the final layout of the paper including the volume, issue and page numbers.

Link to publication

\footnotetext{
General rights rights.

- You may freely distribute the URL identifying the publication in the public portal. please follow below link for the End User Agreement:

www.umlib.nl/taverne-license

Take down policy

If you believe that this document breaches copyright please contact us at:

repository@maastrichtuniversity.nl

providing details and we will investigate your claim.
}

Copyright and moral rights for the publications made accessible in the public portal are retained by the authors and/or other copyright owners and it is a condition of accessing publications that users recognise and abide by the legal requirements associated with these

- Users may download and print one copy of any publication from the public portal for the purpose of private study or research.

- You may not further distribute the material or use it for any profit-making activity or commercial gain

If the publication is distributed under the terms of Article $25 \mathrm{fa}$ of the Dutch Copyright Act, indicated by the "Taverne" license above, 


\section{Maastricht University}

\section{Oratie}

\section{Prof. dr. C.A.B. Webers}

Faculty of Health, Medicine and Life Sciences / MUMC ${ }^{+}$

\section{Glaucoom:}

Druk, druk, druk... 
Glaucoom:

Druk, druk, druk... 


\section{Colofon}

Ontwerp en print: Océ Business Services, Maastricht

ISBN: 978-905-687-3727

NUR: 876

Alle rechten voorbehouden. Niets uit deze uitgave mag worden verveelvoudigd, opgeslagen in een geautomatiseerd gegevensbestand of openbaar gemaakt worden, zonder voorafgaande schriftelijke toestemming van de auteur of uitgever. 


\section{Glaucoom:}

Druk, druk, druk...

Maastricht, og september 20111

Prof. dr. C.A.B. Webers 
Glaucoom: Druk, druk, druk... 
Mijnheer de rector magnificus, geacht college van bestuur, geachte decaan, geachte raad van bestuur, beste collega's, medewerkers, familie, vrienden en overige toehoorders.

\section{Inleiding}

Als exponent van het moderne tijdperk wil ik deze rede beginnen met $u$ de Wikipedia definitie van inauguratie voor te lezen. Overigens moet het voor de raad van bestuur van het Maastricht Universitair Medisch Centrum ${ }^{+}$en het College van Bestuur van de Universiteit Maastricht geruststellend zijn om te weten dat er geen aanleiding is om aan te nemen dat deze rede op Wikileaks zal verschijnen. De inauguratie, volgens Wikipedia, is een formele ceremonie ter gelegenheid van bijvoorbeeld het begin van een ambtstermijn. Het meest gangbare gebruik is in de context van een formele investituur waarbij een individu een positie aanneemt. Dit kunnen staatshoofden, regeringsleiders, pausen en hoogleraren zijn. ${ }^{1} \mathrm{U}$ ziet ik bevind mij niet in het minste gezelschap en $u$ begrijpt nu natuurlijk ook waarom ik Wikipedia als bron heb genomen! Vervolgens echter gaat de definitie verder en stelt dat "...studentenverenigingen ook wel spreken over inauguratie bij het officieel toelaten van nieuwe leden". Ik weet niet wat u van het laatste vindt, maar ik kan u verzekeren dat we straks niet met bier gaan gooien, dat we ook niet gaan brassen en ook de bar van de aula hoeft niet veroverd te worden. $U$ krijgt straks allen gewoon een drankje.

Toch brengt 'de student' mij, bij wat misschien wel de kern van de inauguratie is. Er wordt bij het officieel aanvaarden van de functie namelijk een inaugurele rede uitgesproken. De inaugurele rede, ook wel oratie genoemd, is een openbare redevoering waarmee een nieuw benoemd hoogleraar zijn of haar ambt officieel aanvangt. Hij of zij stelt zich daarmee voor aan de universitaire gemeenschap dus ook aan de studenten. En aangezien ik van de generatie ben die frontaal onderwijs genoten heeft, maar vooral ook van het frontale onderwijs genoten heeft, heb ik gekozen voor het klassieke hoorcollege. Dat betekent dat ik $\mathrm{u}$ in de komende drie kwartier mag onderhouden over de oogheelkunde en meer in het bijzonder over het ziektebeeld glaucoom. Heeft u vragen, opmerkingen of suggesties dan mag u mij gelukkig niet interrumperen. De titel van mijn rede luidt 'Glaucoom: Druk, druk, druk...' En aan het einde van mijn oratie zal duidelijk zijn dat glaucoom grote gevolgen kan hebben voor het individu, een populatie en dé patiënt. 


\section{Deel I. Het individu en glaucoom}

Laat ik beginnen met $u$ uit te leggen wat het ziektebeeld glaucoom is. We hoeven ons daarbij nog niet druk te maken over de patiënt; het gaat nu nog over de ziekte en niet over de zieke.

Voor een beter begrip dienen we eerst, kort, de anatomie van het oog te bestuderen. Op een dwarsdoorsnede van het oog zien we dat lichtstralen uit de omgeving gebroken worden via het hoornvlies en de lens om vervolgens samen te komen op het netvlies. Daar wordt het licht omgezet in impulsen die via de zenuwvezels geleid worden naar de oogzenuw. Van hieruit vindt verder transport van het signaal plaats naar de occipitale cortex waar uiteindelijk verwerking van het signaal plaatsvindt en waarmee we dus zien. Op de verwerking van het signaal en de misleiding die daarbij kan plaatsvinden kom ik zo nog terug.

De ruimte die begrensd wordt door de cornea, de iris en de lens noemen we de voorste oogkamer. Deze ruimte is gevuld met het kamerwater en dit heeft tot doel om de stofwisseling van het voorste oogsegment te verzorgen. Om dit proces te garanderen vindt voortdurende verversing plaats van het kamerwater dat wordt afgevoerd via een zeer gespecialiseerd drainagesysteem in de voorste oogkamerhoek.

Bij glaucoom is nagenoeg altijd sprake van een probleem met de afvoer van kamerwater. De meest voorkomende vorm van glaucoom kenmerkt zich door een drainagesysteem dat onvoldoende functioneert bij een open voorste oogkamerhoek. Er bestaat overigens ook een vorm van glaucoom waarbij de kamerhoek gesloten is, maar deze komt veel minder vaak voor. De afvoerbelemmering leidt tot een ophoping van kamerwater en dit gaat gepaard met een stijging van de oogdruk. De gemiddelde oogdruk in de populatie bedraagt $16 \mathrm{~mm} \mathrm{Hg}$, maar er is ooit afgesproken dat alles wat valt tussen 11 en $21 \mathrm{~mm} \mathrm{Hg}$ als normaal geduid kan worden.

Wanneer we de verdeling van de oogdruk in de bevolking bestuderen dan zien we dat deze scheef naar rechts verdeeld is. Met andere woorden er zijn meer mensen met een statistisch te hoge dan te lage oogdruk. Echter lang niet iedereen met een verhoogde oogdruk krijgt glaucoom! Het omgekeerde komt ook voor. Een niet onaanzienlijk deel van de glaucoompatiënten, misschien wel een derde of zo, heeft nooit een verhoogde oogdruk gehad. We spreken in dat geval van normaal druk glaucoom. Dus je kunt een verhoogde oogdruk hebben zonder glaucoom en omgekeerd glaucoom zonder verhoogde oogdruk. Naast de oogdruk dragen kennelijk andere factoren bij aan het risico op conversie naar glaucoom. 
In geval van een afwijkende oogdruk raakt de oogzenuw beschadigd. Daar waar oogzenuwvezels verloren zijn gegaan kan geen signaal meer geleid worden van het netvlies naar de hersenen. De patiënt neemt daar dus geen of in mindere mate licht meer waar. Omdat de perifere vezels als eerste uitvallen heeft de patiënt aanvankelijk nog niets in de gaten. Naarmate er meer vezels verloren gaan zal de uitval echter ook het centrale gezichtsveld treffen. Een andere reden waarom patiënten pas in een laat stadium klachten krijgen is omdat onze hersenen kennelijk de leemtes in het gezichtsveld invullen met wat ze denken dat er gezien zou moeten worden. Ik refereerde hier eerder al aan door de term 'cerebrale misleiding' te noemen. De plaatjes van onze Belgische collega Ann Hoste illustreren dit fenomeen. Op de foto's met spelende kinderen is te zien hoe de glaucoompatiënt de lacunes invult met wat hij of zij denkt dat er is. De gevolgen zijn evident. Indien het proces niet tot staan gebracht kan worden zal uiteindelijk ook het centrale zien verloren gaan en is de patiënt blind. Dit proces is helaas onomkeerbaar, dus 'weg is weg'! Hoeksteen van de behandeling van glaucoom is het verlagen van de oogdruk tot een niveau waarop geen verdere schade meer zal worden toegebracht. De bovenste limiet van dit niveau wordt de 'target oogdruk' genoemd.

In de laatste 10 jaar hebben we een enorme toename gezien van het aantal beschikbare medicamenten om de oogdruk te verlagen. Voor de scrabbelaars onder u noem ik de alfa-2-adrenerge agonisten, de carboanhydraseremmers, de prostaglandine analogen, de beta-blokkers, de parasympaticomimetica, en allerlei combinaties. De keuze voor een medicament wordt bepaald door vele factoren zoals de mate van oogdrukdaling en het optreden van bijwerkingen. Door resorptie via het neusslijmvlies kunnen oogdruppels ook systemische bijwerkingen geven. Daarnaast weten we dat vele oogdruppels prikken en branden. Een heel aparte bijwerking geven de prostaglandine analogen. Bij patiënten die er gevoelig voor zijn kan een donkere verkleuring van de iris optreden evenals groei en verkleuring van de wimpers. Van dit laatste wordt overigens ook gebruik gemaakt. Deze medicijnen zijn in de Verenigde Staten, waar anders zou ik bijna zeggen, te koop als middel om de wimpers te laten groeien onder de aansprekende naam: Bambi Lashes! 
Het is binnenkort bijna 23 jaar geleden dat ik promoveerde op een proefschrift over de Argon laser trabeculoplastiek. Het doet me deugd dat ik nu tijdens mijn oratie kan vertellen dat de laser nog steeds een krachtig wapen is in de behandeling van glaucoom.

Tenslotte beschikken we over een aantal chirurgische technieken om de oogdruk te doen dalen. De trabeculectomie al dan niet aangevuld met het gebruik van fibroseremmers zoals mitomycine-C of 5 -fluorouracil behoort tot de standaardingrepen in het behandelarsenaal van de glaucoomchirurg. Een tweede chirurgische techniek die in toenemende mate aan populariteit heeft gewonnen is de Glaucoma Filter Implant bv van het type Baerveldt.

\section{Deel II. Een populatie en glaucoom}

Nadat ik $u$ heb verteld wat glaucoom is en wat het betekent voor het individu wil ik graag verder gaan met het bespreken van een aantal aspecten dat een idee geeft over wat glaucoom betekent voor een populatie.

Glaucoom is de belangrijkste oorzaak van vermijdbare blindheid. Er zijn wereldwijd meer dan 100.000.000 mensen met glaucoom en er zijn tenminste 8.000.000 mensen blind door glaucoom. ${ }^{2}$ Voor Nederland zijn weinig exacte cijfers bekend. Uit het ERGO onderzoek in Rotterdam komt een prevalentiecijfer van 1,1\%. Een andere bron is het Centrum Volksgezondheid Toekomst Verkenningen van het Rijksinstituut voor Volksgezondheid en Milieu volgens welke in 2007 ruim 108.000 mensen in Nederland glaucoom hadden. 3 Indien we uitgaan van het voor een westers land in de literatuur gebruikte prevalentiecijfer van $2 \%$ dan kom je voor 2010 uit op 165.000 glaucoom patiënten in Nederland. Glaucoom vormt een aanzienlijke belasting van de oogheelkundige praktijk en geeft daarom niet alleen bij de patiënt maar ook bij de oogarts druk. Ik geef u enkele voorbeelden die de belasting van de praktijk illustreren.

- Glaucoompatiënten komen gemiddeld twee tot driemaal per jaar ter controle bij de oogarts. En dit voor de rest van hun leven.

- Verder dient bij glaucoompatiënten met enige regelmaat een gezichtsveldonderzoek verricht te worden. Bij twijfel over verslechtering moet dit gezichtsveld herhaald worden. En een gezichtsveldonderzoek duurt al gauw 30 minuten. 
- Ook nemen de mogelijkheden voor diagnostiek toe. In het Oogziekenhuis Maastricht UMC beschikken we thans over de Optical Coherence Tomograph, de Heidelberg Retina Tomograph, de Nerve Fiber Analyzer, de Visante OCT, de Scheimpflug Imaging, Pachymeters en non-mydriatic fundus camera's. Deze apparatuur verbetert de mogelijkheid tot diagnostiek maar vergt ook onderzoekstijd.

- Een deel van de glaucoompatiënten zal behandeld moeten worden middels laser of chirurgie. En met name dit laatste vraagt een intensieve nabehandeling.

- De toeloop van mensen met een verhoogde oogdruk is bovendien gestegen door de beschikbaarheid van zogenaamde non-contact tonometers bij de opticiens ('luchtdrukmeters'). Voordeel van deze apparatuur is dat patiënten met een verhoogde oogdruk worden opgespoord. Nadeel is dat deze apparatuur in het algemeen een te hoge oogdruk meet met als consequentie dat ook veel mensen met een vermeend verhoogde oogdruk naar ons verwezen worden.

- Ook zeggen wij tegen glaucoompatiënten dat ze hun eerste graads familieleden moeten adviseren zich te laten controleren op glaucoom.

- Tel daar tenslotte nog eens de dubbele vergrijzing bij op, in 2025 ben ik hopelijk 65 jaar en samen met mij 1 op de 5 Nederlanders, en al met al geeft dit een aanzienlijke belasting van de werkzaamheden van de oogarts.

$U$ begrijpt dat tegen het licht van deze praktijkbelasting de animo onder oogartsen om tot screeningsprogramma's op glaucoom over te gaan slechts gering is. Naast de capaciteitsproblemen in de oogzorg speelt hier nog iets anders een rol. Om te voldoen aan de WHO criteria om voor screening in aanmerking te komen dient een ziektebeeld onder andere 4 : (1) een belangrijk gezondheidszorgprobleem te zijn,

(2) behandelbaar te zijn,

(3) in de latente fase herkenbaar te zijn en

(4) moet er een test of onderzoek beschikbaar zijn.

Aan de eerste 3 criteria voldoet glaucoom zonder meer, het laatste echter is een probleem. Uiteraard hebben we apparatuur waarmee we op glaucoom kunnen testen en zelfs steeds meer apparatuur, zoals ik u net schetste. Echter, de sensitiviteit en specificiteit van deze apparatuur is 
redelijk, maar niet goed genoeg om tot screening van de bevolking over te gaan. Een dergelijke screening zou teveel zogenaamde fout-positieve gevallen opleveren. Niet alleen in Nederland maar ook elders op de wereld is men dan ook de mening toegedaan dat een screeningsprogramma voor glaucoom in de algemene bevolking afgeraden moet worden.

Maar wat moeten we dan nu zult u zich afvragen. Immers glaucoom komt kennelijk veel voor, is tamelijk goed te behandelen en heeft onbehandeld grote consequenties voor de visuele functie. Wel, daartoe zal ik een aantal oplossingen aandragen die wij in Maastricht geformuleerd hebben en die kunnen gaan bijdragen aan het kanaliseren van het probleem.

1. Ten eerste denk ik bij oplossingen aan taakherschikking. Volgens een advies uitgebracht door de Raad voor de Volksgezondheid en Zorg aan de minister van Volksgezondheid, Welzijn en Sport in 2002 wordt taakherschikking gedefinieerd als: 'het structureel herverdelen van taken tussen verschillende beroepen waarbij niet de functie centraal staat. Taken worden niet anders over functies verdeeld, maar over beroepen of beroepsgroepen.' 5 Een voorbeeld van taakherschikking betreft de functie van optometrist binnen de oogzorg. Optometrist is een $\mathrm{BIG}$ geregistreerd beroep en behelst het screenen van patiënten op oogaandoeningen en het op verwijzing van een huisarts of oogarts uitvoeren van vervolgonderzoeken.

Sinds 1998 ben ik nauw betrokken geweest bij het adequaat positioneren van de functie van optometrist in de Nederlandse oogzorg. In samenwerking met de Universiteit Maastricht werd een oogzorg model ontwikkeld. In 2003 publiceerden Frans van der Horst, Silvia Bours en ik het rapport getiteld Transmuraal Model Oogzorg; ontwikkeling, implementatie en evaluatie van een regionaal samenwerkingsverband.6 Menig collega oogarts meende op basis van onterechte a priori aannames ons model te kunnen gebruiken om de ontwikkelingen op dit terrein te frustreren. Niets is echter minder waar! Ons model heeft op vele plaatsen navolging gekregen. Consequentie is wel geweest dat ik een aantal keren op de schouders een zaal ingedragen ben om een voordracht te houden over die 'vermaledijde' taakherschikking, maar er na mijn pleidooi nog net niet met pek en veren uit verwijderd werd!

De wal keert echter zoals altijd het schip en gebleken is dat intramurale optometristen zeer wel in staat zijn om deeltaken van oogartsen over 
te nemen. Dit geldt onder voorwaarden ook voor extramuraal werkende optometristen. Het is dan ook dankzij de Maastrichtse inspanningen dat zich op dit terrein 2 ontwikkelingen voordoen. Op de eerste plaats is mede namens de Nederlandse Glaucoom Groep en in samenwerking met de collega's uit het UMC Groningen en het Oogziekenhuis Rotterdam een glaucoomrichtlijn ontworpen die de extramuraal werkende optometrist een schema biedt met adviezen hoe te handelen bij een patiënt met verdenking op glaucoom. En op de tweede plaats zal de Glaucoomgroep van het Oogziekenhuis Maastricht UMC de eerste officiële glaucoom nascholing van de optometrieopleiding van de Hoge School Utrecht verzorgen. Mede door deze ontwikkelingen pleit ik dan ook voor een nog bredere inzet van optometristen in de oogzorg en dan met name ook binnen het glaucoom. En daarmee kan het opleiden van nog meer oogartsen beperkt worden.

2. Een tweede oplossing om het kwantitatieve glaucoomprobleem te kanaliseren is het gebruik van richtlijnen. Door de glaucoom groep uit Maastricht wordt op twee manieren bijgedragen aan het implementeren van richtlijnen binnen de diagnostiek en behandeling van glaucoom. Beide bijdragen zijn overigens uitvloeisels van een grote nationale studie die door de afdeling Oogheelkunde van het azM op initiatief van Jan Schouten werd uitgevoerd en die de titel heeft: The Dutch Research Project on Treatment Outcome in Glaucoma patients, de DURING studie.

Binnen de During studie hebben we onder andere gekeken naar het gebruik van een behandelprotocol door oogartsen Hierbij valt op dat nietgebruikers van behandelprotocollen zich onderscheiden in hun attitude ten opzichte van protocolgebruik in het algemeen. Een aanbeveling van een formeel onderdeel van de beroepsgroep, in dit geval de Nederlandse Glaucoom Groep of het Nederlands Oogheelkundig Gezelschap, nodigt echter uit tot het wél gaan gebruiken van het protocol. Ik ben dan ook van mening dat deze leerstoel via het Nederlands Oogheelkundig Gezelschap het implementeren van richtlijnen op dit onderwerp kan faciliteren. Een tweede aspect van de During studie dat relevant is geweest en nog steeds is, betreft de samenvatting van de wetenschappelijke literatuur als onderlegger voor een richtlijn. De door onze onderzoeksgroep gepubliceerde systematische reviews hebben bijgedragen aan de wetenschappelijke basis van de meest recente versie van de 
Terminology and Guidelines for Glaucoma of the European Glaucoma Society ${ }^{7}$ die inmiddels aangenomen is door het Nederlands Oogheelkundig Gezelschap als richtlijn voor de diagnostiek en behandeling van glaucoom. Het uitdragen van de onderbouwing van deze manier van bewijsvoering alsook van de resultaten op zich beschouw ik als een belangrijke opdracht van deze leerstoel.

3. Een derde bijdrage aan het kanaliseren van het glaucoomprobleem is gelegen in een focus op progressie. Het belang van het detecteren van progressie bij glaucoom spreekt voor zich. Probleem is dat een gouden standaard ontbreekt en er veel wetenschappelijk debat is over de criteria hoe progressie gemeten moet worden. De relatie tussen 'structure' (afwijkingen aan de oogzenuw) en 'function' (gemeten gezichtsvelduitval) is niet altijd helder en evenmin is duidelijk in hoeverre structurele schade, die meestal voorafgaat aan functionele schade, reeds consequenties heeft voor de door de patiënt gepercipieerde kwaliteit van leven.

De mate van progressie verschilt nogal tussen patiënten. Veel patiënten vertonen een slechts zeer langzame progressie na adequate oogdruk-daling terwijl anderen progressief blijven na soms een forse daling van de oogdruk. Naast de oogdruk zijn er dus andere factoren die de mate van progressie bepalen. Het is daarom van belang om het risicoprofiel van een individuele patiënt te kennen. Ons wetenschappelijk onderzoek zal zich in ieder geval op 2 groepen factoren richten. De eerste groep betreft de vasculaire factoren die een rol spelen bij de conversie en progressie van glaucoom. Van belang hierbij is of op basis van systemische en oogheelkundige patiëntkenmerken met betrekking tot doorbloeding een 'prognostisch profiel' beschreven kan worden. Daarnaast is het van belang om te onderzoeken of oogheelkundige dan wel systemische medicatie dit profiel ten gunste kan beïnvloeden. Dit onderzoek kan uitgevoerd worden in de DURING studie en in de zojuist begonnen Maastricht studie. De tweede groep betreft genetische factoren. Alhoewel er congenitale en juveniele vormen van glaucoom zijn die een Mendeliaanse overerving kennen geldt voor primair open kamerhoek glaucoom dat deze veelal een complexe vorm van overerving heeft. Onderzoek op dit terrein zal zich onder andere richten op de relatie tussen de mate van progressie van glaucoom en het voorkomen van genpolymorphismen en daarnaast het effect van genpolymorphismen op de mate van oogdrukdaling en het 
optreden van bijwerkingen bij het gebruik van oogdrukverlagende medicamenten.

4. Tenslotte kan herverdeling van financiële middelen bijdragen aan de oplossing van het glaucoomprobleem. En dit vraagt om kosteneffectiviteitsanalyses. Het chronisch progressieve karakter van glaucoom maakt onderzoek met betrekking tot de lange termijn effecten lastig. En als directeur-bestuurder van de Resultaat Verantwoordelijke Eenheid Operatieve Geneeskunde, de grootste eenheid van het $\mathrm{MUMC}^{+}$, weet ik dat maatschappelijke ontwikkelingen een steeds betere verantwoording vragen van de uitgaven in de gezondheidszorg. De vragen naar kosten en effecten van behandelingen komen nu of in de nabije toekomst van de overheid, de zorgverzekeraars, de zorginstellingen, de patiëntenbelangenorganisaties, de consumentenorganisaties, de beroepsgroepen, de collega's, de media en niet in de laatste plaats van patiënten. Alhoewel de laatste groep terecht vooral in de effecten geïnteresseerd is en minder in de kosten. Het lijkt mij passend om de positie die deze leerstoel genereert in te zetten voor een streven naar transparantie omtrent kosten en opbrengsten van dat wat wij doen. Een van de manieren om deze transparantie te genereren is het verrichten van kosteneffectiviteitstudies. Het gebruik van modellen heeft daarbij grote voordelen boven het uitvoeren van empirisch onderzoek. In een model dat binnen onze afdeling door Aukje van Gestel werd ontworpen wordt de progressie van glaucoom bij individuele patiënten bij verschillende behandelstrategieën nagebootst. ${ }^{8}$ Dit heeft geleid tot een valide en flexibel gezondheidseconomisch model op basis van 'discrete event simulation' dat op een interactieve manier gebruikt kan worden bij het ontwikkelen van behandelrichtlijnen voor oculaire hypertensie en glaucoom.

Een van de belangrijke opbrengsten van het model wil ik $u$ niet onthouden. Wij hebben een cohort van 3000 fictieve patiënten gemodelleerd. Daarbij zijn we uitgegaan van 2 scenario's: huidige zorg versus geen behandeling. De huidige zorg was zoveel mogelijk een afspiegeling van onze dagelijkse praktijk dus inclusief alle reguliere controles, gezichtveldonderzoeken, medicaties, laserbehandelingen, chirurgie, kosten voor blindheid en overige kosten zoals reiskosten en kosten voor mantelzorgers. Als we het 
model deze strategie laten doorrekenen dan blijkt de huidige behandeling van glaucoom een uitermate kosteneffectieve benadering. Aan het eind van het ziekteproces heb je gezondheidseffecten gewonnen en zelfs kosten bespaard. Enige nuancering in de uitkomsten moet ik echter aanbrengen. In ons model hebben we gekozen voor het zogenaamde maatschappelijk perspectief. Dat wil zeggen dat we alle kosten hebben meegenomen. En de kosten die je bespaart door glaucoom te behandelen worden vooral laat in het ziekteproces gegenereerd, dat zijn namelijk de kosten van blindheid. $U$ kunt zich voorstellen dat blindheid duur is door de verstrekking van hulpmiddelen maar ook door intensiteit van de te verlenen zorg. Probleem is dus dat de behandeling van glaucoom een uitermate kosteneffectieve strategie is, maar dat je nú moet investeren om in de toekomst kosten te besparen. En wellicht is een verzekeraar minder bereid om nu dure medicijnen te vergoeden ook al levert het later geld op door minder uitgaven in het kader van de AWBZ. Of is een ziekenhuis minder bereid om nu een niet-kostendekkende operatie te laten verrichten om later op maatschappelijk niveau geld te besparen. Het doet me een beetje denken aan de slogan van de banken... "rendementen uit het verleden bieden geen garantie voor de toekomst". Om te voorkomen dat de behandeling van glaucoom gezien wordt als een soort woekerpolis zal ik me dan ook inzetten om de kosteneffectiviteit van de behandeling van glaucoom in het juiste perspectief te blijven plaatsen.

\section{Deel III. De patiënt en glaucoom}

In dit laatste deel kom ik tot de kern van de zaak, de glaucoompatiënt. Patiënt is afkomstig van het Latijnse patientia hetgeen lijden, volharding of geduld betekent. En alle 3 de betekenissen hebben betrekking op glaucoom, zo zal blijken. De patiënt heeft in tegenstelling tot het individu of de populatie een gezicht. Laat ik $u$ daarom het verhaal vertellen van $M W$. W., één van mijn glaucoompatiënten.

Mw. W. ken ik sinds mei 1986, dus al meer dan 25 jaar. Ik zat toen in militaire dienst en was tegelijkertijd in het St. Radboud Ziekenhuis onder leiding van Professor Hendrikse bezig met een onderzoek naar de effecten van de laserbehandeling van glaucoom. Mw. W. was een van de patiënten die in het prospectieve deel van het onderzoek participeerde. Ze heeft op tamelijk 
jonge leeftijd glaucoom gekregen waarvoor ze diverse behandelingen heeft ondergaan. Aanvankelijk medicamenteus, daarna laser, toen weer medicamenteus en uiteindelijk heb ik haar aan beide ogen geopereerd. En ik mag zeggen met goed gevolg. De oogdruk is genormaliseerd en er is betrekkelijk weinig schade aan de oogzenuw en het gezichtsveld. Mw. W. weet als geen ander dat glaucoom een verraderlijk ziektebeeld is; ze heeft meegemaakt dat haar vader nagenoeg blind geworden is: "...dat nooit, dokter!". Kennelijk ervaart ze dit als een druk op de door haar gepercipieerde kwaliteit van leven. Een aantal keren per jaar komt ze ter controle in ons ziekenhuis in Maastricht. In de buurt van waar ze woont, net ten noorden van Nijmegen, zijn overigens ook prima oogartsen werkzaam, maar ze blijft liever naar Maastricht komen. Vanzelfsprekend, denk ik dan maar. Bij de reguliere controles nemen we de lopende familie-, en bedrijfszaken even door en vraagt zij ook steevast naar mijn persoonlijke omstandigheden; na 25 jaar weet je namelijk wel iets van elkaar. Door de moderne laboratoriumtechnieken hebben we achterhaald dat in de familie een mutatie voorkomt in het MYOC gen. MW.W. is sinds de diagnose 119 keer ter controle geweest. Ik zal haar uiteraard blijven monitoren en behandelen volgens de maatstaven die gelden, maar die door de ontwikkelingen in de wetenschap, maar ook door veranderingen in haar persoonlijke omstandigheden continue adaptatie vragen van beide partijen.

Tot zover de casus. Waarom vertel ik $u$ dit alles? Allereerst illustreert deze casus de chroniciteit van het ziektebeeld. Glaucoom is een van meest chronische ziektebeelden die we in de oogheelkunde kennen. Veel andere oogaandoeningen gaan na conservatieve behandeling over of kunnen worden geopereerd. Sommige ziekten gaan misschien wel vanzelf en zonder behandeling over. Of iemand is niet meer te behandelen, blijft slechtziende en wordt verder opgevangen in het 'low-vision' circuit. De glaucoompatiënt echter niet; de glaucoom patiënt heeft als het ware levenslang. En daarmee de glaucoomdokter ook! Verder is aan de hand van deze casus het concept van evidencebased medicine goed te illustreren en dit concept is bij uitstek toepasbaar op het ziektebeeld glaucoom. Wat we in ieder geval niet bedoelen met evidence-based medicine is het puur en alleen formuleren van richtlijnen en protocollen om artsen daarmee in een keurslijf te dwingen zonder dat daarbij de afwegingen gemaakt worden waar een individuele patiënt recht op heeft. Dit heeft mij in het verleden er wel eens toe gebracht een voor- 
dracht te houden met de titel: 'evidence-based medicine: het evidence beest is los!'

De definitie van Offringa, Assendelft en Scholten9 luidt als volgt: 'evidence-based medicine is het zorgvuldig, expliciet en oordeelkundig gebruik van het huidige beste bewijsmateriaal om beslissingen te nemen voor individuele patiënten. De praktijk van evidence-based medicine impliceert het integreren van individuele klinische expertise met het beste externe bewijsmateriaal... De voorkeuren, wensen en verwachtingen van de patiënt spelen bij de besluitvorming een centrale rol'.

Om op zoek te gaan naar het beste externe bewijsmateriaal voor de diagnostiek en behandeling van glaucoom hebben we destijds binnen de DURING studie de systematische review en meta-analyse als onderzoekstechniek geïntroduceerd. Een systematische review van de literatuur wordt immers gezien als de hoogste vorm van wetenschappelijk bewijs en kenmerkt zich door een expliciete wetenschappelijke vraagstelling, een gedefinieerde zoekstrategie, het gebruik van in-, en exclusie criteria, het gebruik van kwaliteitscriteria, een objectieve wijze van data extractie en tenslotte een metaanalytische synthese van data. Door onze glaucoomonderzoeksgroep werden systematische reviews verricht naar oogdrukverlagende medicijnen, naar combinaties van medicijnen, naar het effect van oogdrukdaling op de conversie van oculaire hypertensie naar glaucoom en de progressie van glaucoom, naar het gebruik van perimetrische technieken, naar compliance en adherence van glaucoommedicatie en naar prognostische factoren bij glaucoom. Deze reviews behoren tot de meest geciteerde studies die door de afdeling oogheelkunde van het $\mathrm{MUMC}^{+}$werden geproduceerd en worden wereldwijd als zeer waardevol ervaren.

Ten aanzien van de voorkeuren, wensen en verwachtingen van de patiënt het volgende. In de beschreven casus weet de individuele patiënt dat het eindstadium van glaucoom een schrikbeeld is. Niet omdat de oogdruk te hoog is, of de oogzenuw beschadigd is of omdat er gezichtsvelduitval is. Dit zijn voor de patiënt ook maar secundaire uitkomstmaten van de behandeling. Bij de voorkeuren, wensen en verwachtingen van de glaucoompatiënt speelt de impact op de gepercipieerde kwaliteit van leven waarschijnlijk de grootste rol. Ik heb talloze definities van kwaliteit van leven gevonden, maar er was er niet een die me beviel. Toch weten $u$ en ik wat met kwaliteit van leven bedoeld wordt. Wat we ook weten is dat kwaliteit van leven, 
net als de oogdruk of het gezichtsveld, meetbaar is. Als het gaat om gezondheidsgerelateerde kwaliteit van leven dan kun je gebruik maken van generieke, ziektespecifieke en domeinspecifieke vragenlijsten. Dit laatste is van belang omdat $u$ kunt aanvoelen dat bij kwaliteit van leven verschillende domeinen een rol spelen: het lichamelijke, psychische en sociale domein. En het zijn de verschillende domeinen en dimensies van kwaliteit van leven die een rol spelen bij de afwegingen die gemaakt worden bij de behandeling van glaucoom. Het laatste wat ik hiermee wil suggereren is dat we in onze spreekkamer als halfbakken, zelfbenoemde psychologen onze patiënten al 'Rogeriaans' murmelend op een jaren-70 geschoeide leest van '...en wat vindt u er nou zelf van...' wijze moeten benaderen! Integendeel. Het is juist de patiënt die van ons verwacht dat we de kille feitelijkheid van de harde data uit de wetenschappelijke literatuur weten te vertalen naar de situatie en de belangen van de individuele patiënt. Het Maastrichtse onderzoek naar de relatie tussen glaucoomparameters en kwaliteit van leven sluit hier naadloos op aan.

Maar soms, misschien wel vaker dan we willen of durven toegeven, is er geen beste externe bewijs. De patiënt is dan afhankelijk van de individuele klinische expertise van zijn of haar oogarts. Al te gemakkelijk wordt naar mijn mening deze individuele klinische expertise onderbouwd met de op veel congressen gebruikte frase, zeker daar waar het gaat om chirurgie, "in my hands". Er zijn naar mijn mening betere manieren om te borgen dat de individuele klinische expertise binnen het glaucoom stoelt op een deugdelijk fundament.

Ik wil er 3 noemen.

1. Op de eerste plaats door het organiseren van formele fellowships in de oogheelkunde. Dit betekent dat iemand eerst wordt opgeleid tot oogarts en zich vervolgens gedurende 1 of 2 jaar verder bekwaamt in een subspecialisme, in dit geval glaucoom. Na een dergelijk fellowship kun je dan als glaucoomspecialist gaan werken in een academisch centrum of een grotere niet-academische praktijk. Een dergelijk fellowship dient gepaard te gaan met rechten en plichten van zowel de fellow als het instituut waar het fellowship kan plaatsvinden. Als vooralsnog waarnemend opleider ga ik mij sterk maken binnen het concilium ophthalmologicum om een formele positie te realiseren voor de glaucoom fellowships in de Nederlandse oogheelkunde. 
2. Een tweede manier om de individuele expertise te borgen is door het aanleggen van een landelijk register voor glaucoomchirurgie. In tegenstelling tot bijvoorbeeld de cataractoperatie die steeds meer afhankelijk is van technische apparatuur behoort de glaucoomchirurgie tot de meer conventionele vormen van operatief ingrijpen in de oogheelkunde. De uitkomst is maar ten dele voorspelbaar. Er lijkt een verband te bestaan tussen enerzijds het aantal operaties dat een chirurg verricht en anderzijds de kans van slagen en het risico op complicaties. Ik zal dan ook de eis tot een minimum aantal van deze ingrepen per glaucoomchirurg, analoog aan ontwikkelingen in aanpalende vakgebieden, te zijner tijd onderschrijven. Een landelijk register zou de mogelijkheid bieden om de eigen operatie resultaten bij te houden en te spiegelen aan de resultaten van overige chirurgen. Dat geeft in ieder geval de mogelijkheid maar ook de impuls tot reflectie en waar nodig verbetering.

3. Een derde manier van borgen van expertise is het benoemen van kwaliteitsindicatoren voor glaucoom. In de huidige tijd worden wij als organisatie en als individuele dokters in toenemende mate gevraagd om transparant te zijn over de uitkomsten van de verleende zorg. Het idee dat dit fenomeen zal uitdoven is een foute en vooral ook onprofessionele taxatie. Sterker nog, we zullen alleen nog maar meer bevraagd gaan worden. Een van de manieren om te voorkomen dat de angst voor misbruik en misinterpretatie van informatie bewaarheid wordt is het proactief meedenken en formuleren van de juiste set van indicatoren. Glaucoom is zowel op procesniveau als inhoudelijk goed kwantificeerbaar en ik ben dan ook blij dat ik samen met 2 collega's gevraagd ben om de indicatorset voor glaucoom mede gestalte te geven in Nederland.

\section{Tenslotte}

Dames en Heren. Ik heb $u$ uitgelegd wat glaucoom is. Het is een oogziekte die veel te maken heeft met druk, dat weet $u$ nu in ieder geval. Door een verhoogde oogdruk ontstaat schade aan de oogzenuw met als gevolg gezichtsvelduitval. Ik heb laten zien dat glaucoom in kwantitatieve zin een groot probleem is en een forse belasting voor de oogheelkundige praktijk. Ook heb ik een aantal Maastrichtse bijdragen tot de oplossing benoemd $\mathrm{nl}$ taakherschikking, toepassen van richtlijnen, focus op progressie en kosteneffectiviteitsanalyses. 
Tenslotte heb ik het gehad over de glaucoompatiënt en hoe het beste externe bewijsmateriaal en de klinische expertise samen tegemoet komen aan de voorkeuren, wensen en verwachtingen van een individuele patiënt.

Laat me als afsluiting van de rede enige 'stichtelijke' woorden richten tot de oogartsen in opleiding. De oogarts die er voor kiest om glaucoomspecialist te worden, moet weten dat hij of zij dient te beschikken over een lange adem, veel geduld en doorzettingsvermogen. En vooral een persoonlijke betrokkenheid bij de individuele patiënt. De 'glaucoomdokter' moet de kunst verstaan om niet te verzuren of cynisch te worden. Goede glaucoomzorg laat zich volgens mij het beste vertalen in 'personalized care.' Met andere woorden: de oogarts biedt hooggekwalificeerde, gespecialiseerde medische behandeling én individuele, persoonlijke zorg met als doel een leven lang behoud van visuele functies en daarmee van kwaliteit van leven. 


\section{Dankwoord}

Als afsluiting wil ik enige woorden van dank uitspreken.

Ik dank het College van Bestuur van de Universiteit Maastricht voor het vertrouwen dat ze in mij stellen.

Ook dank ik de Raad van Bestuur van het Academisch Ziekenhuis Maastricht voor de uitstekende samenwerking op bestuurlijk en ander vlak. Ik hoop dat deze samenwerking zich op een zelfde manier zal continueren binnen mijn toekomstige functie als hoofd van de afdeling oogheelkunde.

Ik ben mijn opleider, August Deutman, dankbaar voor het feit dat hij mij destijds in opleiding heeft genomen. Overigens moest ik daartoe wel eerst 'even' promoveren.

Het eerste contact met Fred Hendrikse dateert uit 1984. Ik begon als student en hij werd mijn begeleider in het daaropvolgend promotieonderzoek. Tegen het einde van mijn opleiding wist hij me te overtuigen dat ik met hem naar Maastricht moest gaan. In bijna 20 jaar is hier onder zijn unieke en kenmerkende leiding een Euregionaal oogheelkundig 'concern' ontstaan dat zijn voorlopige apotheose heeft bereikt met het betrekken van de Oogtoren. Fred, ik ben je buitengewoon en oprecht dankbaar voor alle kansen die je me geboden hebt. Per 1 januari 2012 word ik afdelingshoofd en blijf jij nog een tijdje opleider. Hoe zal dat aflopen, denkt menigeen? Wel nu, dames en heren, dat gaat prima aflopen! Na bijna 27 jaar samenwerking weten wij wel hoe dat moet.

Ook bedank ik de staf van het Oogziekenhuis Maastricht UMC voor de zeer plezierige samenwerking. Jullie zullen er hopelijk begrip voor hebben dat ik sommigen met naam wil noemen.

Allereerst Henny Beckers. Wij zijn op de dezelfde dag begonnen op de afdeling, 1 maart 1993. Ik als jongste staflid, jij als jongste oogarts-in-opleiding. Inmiddels zijn we al geruime tijd compagnons in het glaucoom. Je bent een collega naar mijn hart: betrouwbaar, zeer kundig en bovenal loyaal. Ik hoop op nog een lange samenwerking! 
Astrid Hacking, euregionaal manager. Wiskundeknobbel, tactisch wonder, spin in het web. Dank voor je inzet voor de afdeling, 24 uur per dag, 7 dagen per week. Ik verheug me op onze nog intensievere coöperatie.

Ook Rudy Nuijts noem ik met naam. Hoe moet je ons samenwerkingsverband noemen? Concullega's vind ik wel treffend. En zo hoort het in een professionele organisatie. Ik gaf je ooit een boekje over Atilla de Hun. Bij een biertje nemen we dat nog een keer door.

Als laatste van de staf wil ik Jan Schouten noemen. Het is mede dankzij jouw inzet dat het wetenschappelijk glaucoomonderzoek in Maastricht structuur heeft gekregen. Ik ben je hier zeer erkentelijk voor en heb jou in ruil daarvoor de passie voor dit mooie vak proberen mee te geven.

In één adem, en daarbij doe ik velen individueel tekort, bedank ik alle medewerkers van de afdeling oogheelkunde van het Academisch Ziekenhuis Maastricht, het Medisch Centrum Maastricht Annadal, het Atrium Medisch Centrum Parkstad, het ZorgSaam en het Admiraal de Ruyter Ziekenhuis in Zeeland en onze Belgische Kliniek in St. Truiden. Mensen maken de organisatie. Namens alle patiënten dank ik jullie voor de niet aflatende inzet!

Van de RVE Operatieve Geneeskunde dank ik het gehele management team, het secretariaat en de leidinggevenden. Ik noem jullie niet bij naam, ook om te voorkomen dat 'ze' zeggen: die hebben een hoop personeel! Er is er echter één die ik wel noem en dat is Inge ter Laak. Wat ik allemaal van je geleerd heb is teveel om op te noemen. Ik kan wel zeggen dat ik je er zeer dankbaar voor ben.

Dank aan, maar vooral ook respect voor mijn ouders. Hard werken, niet klagen, vallen, opstaan en gewoon weer doorgaan. Dat zijn de ingrediënten voor succes. Jullie zijn daarin mijn voorbeeld geweest.

Mijn schoonouders mogen deze dag helaas niet meer meemaken. Ik ben hun dankbaar voor alle steun die Marianne en ik ruim 30 jaar lang hebben gekregen. 
Mijn zusje Paddy, haar echtgenoot Mick en hun kinderen noem ik want van je familie moet je het hebben. En dat is ook echt zo. Het is fantastisch om te zien hoe onze gezinnen met elkaar op trekken!

Net als aan het begin van de rede richt ik mij tot de student maar dan in meer persoonlijke zin, namelijk tot onze 3 studerende kinderen. Beste Casper, Valentijn en Frédérique. Jullie vertellen me dat het studentenleven van nu niet te vergelijken is met dat van vroeger. Wat ik echter uit jullie verhalen hoor is dat het nog steeds de spannendste tijd van je leven kan zijn. Mijn advies: sla je vleugels uit, doe wat met je talenten en natuurlijk maar waarschijnlijk ten overvloede...... maak ook genoeg plezier!

En tot slot Marianne. We delen al 32 jaar lief en leed. Ik heb steeds kunnen rekenen op jouw onvoorwaardelijke steun. Het feit dat ik hier kan staan is ook jouw verdienste. Ik ben je daar zeer dankbaar voor.

Ik heb gezegd! 


\section{Referenties}

1. Wikipedia. De vrije encyclopedie. Definitie van inauguratie. Beschikbaar op URL http://nl.wikipedia.org/wiki/inauguratie. [18 april 2011]

2. Quigley HA. Number of people with glaucoma worldwide. Br J Ophthalmol. 1996 May;80(5):389-93.

3. Nationaal Kompas Volksgezondheid. Cijfers gezichtsstoornissen (prevalentie en incidentie) uit de VTV 2010. Beschikbaar op URL http://www.nationaalkompas.nl/gezondheid-en-ziekte. [21 april 2011]

4. Nolan W, Yip J. Screening for Glaucoma. In: Glaucoma Volume 1: Diagnosis and Therapy. Elsevier, 2009

5. Taakherschikking in de gezondheidszorg. Advies uitgebracht door de Raad voor de Volksgezondheid en Zorg aan de minister van Volksgezondheid, Welzijn en Sport. Zoetermeer, 2002

6. Van der Horst FG, Webers CAB, Bours SJM. Transmuraal Model Oogzorg. Datawyse: Maastricht, 2003

7. European Glaucoma Society. Terminology and Guidelines for Glaucoma. II ${ }^{\text {nd }}$ Edition. Dogma. Savone-Italie, 2003.

8. Gestel van A, , Severens JL, Webers CAB, Beckers HJM, Jansonius NM, Schouten JSAG. Modeling complex treatment strategies: construction and validation of a discrete event simulation model for glaucoma. Value in Health 2010;13:358-67

9. Offringa M, Assendelft WJJ, Scholten RJPM: Inleiding in evidence based medicine. Bohn Stafleu van Loghum. Tweede, herziene druk, vierde oplage, 2007 . 
